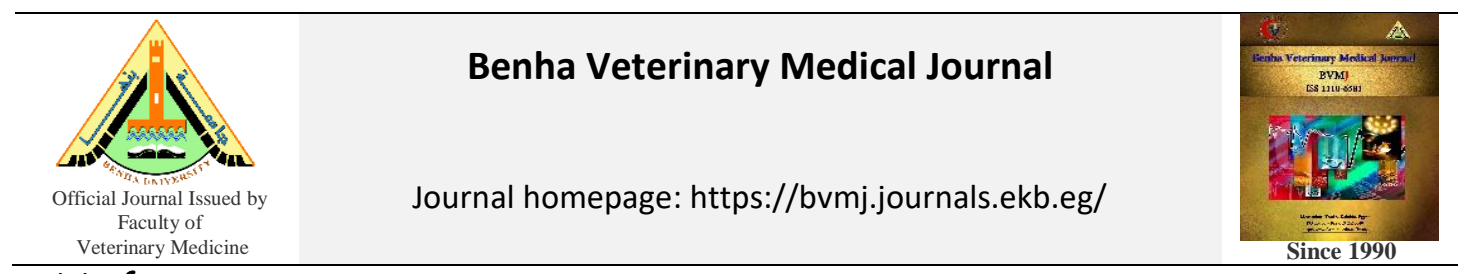

Original Paper

\title{
Multiplex PCR assay for molecular identification of Brucella strains including the vaccinal strains and its differentiation from Yersinia $0: 9$
}

\author{
Ashraf A. Abd El-Tawab ${ }^{1 *}$, Fatma El-Hofy ${ }^{1}$, Medhat Sadk ${ }^{2}$, Rania Abo-Sakaya ${ }^{3}$, Mohamed Ebrahim ${ }^{2}$, \\ Amany Baghdadi ${ }^{2}$ \\ ${ }^{I}$ Department of Bacteriology, Faculty of Veterinary Medicine, Benha University \\ ${ }^{2}$ Veterinary Serum and Vaccine Research Institute, Cairo, Egypt \\ ${ }^{3}$ Department of Animal Medicine, Faculty of Veterinary Medicine, Benha University
}

\begin{tabular}{|c|c|}
\hline ARTICLE INFO & ABSTRACT \\
\hline $\begin{array}{l}\text { Keywords } \\
\text { Brucella Typing } \\
\text { Multiplex PCR } \\
\text { Molecular identification } \\
\text { Yersinia enterocolitica }\end{array}$ & $\begin{array}{l}\text { In this comparative study, five Brucella strains were morphologically, serologically, and } \\
\text { biochemically identified using media different stains and antibiotics. Multiplex PCR was used } \\
\text { to differentiate between the Brucella strains and Yersinia enterocolitica } O \text { : } 9 \text {. five primer sets } \\
\text { were designed to the most specific variable regions of the different Brucella species. The results } \\
\text { of multiplex PCR were very successful and accurate in terms of characterization and typing of } \\
\text { the Brucella vaccine, reference and wild Brucella strains from Yersinia which gave false } \\
\text { positive while using tests based on anti-LPS antibodies but with PCR for DNA of Yersinia gave } \\
\text { negative. The molecular typing of the Brucella strains by multiplex PCR had several } \\
\text { advantages over the use of the conventional methods being very fast, precise, easier, more } \\
\text { sensitive, and economic and could be applied on minimal sample preparation. The development } \\
\text { of this PCR method is the first step toward the development of a novel kit for the molecular } \\
\text { identification of Brucella strains from other Gram- negative bacteria. }\end{array}$ \\
\hline
\end{tabular}

\section{INTRODUCTION}

Brucellosis is caused by a facultative intracellular bacterium of the genus Brucella. Brucella is virulent mainly due to their ability to avoid the bactericidal phagocyte functions and to proliferate within macrophages, leading to the establishment of a chronic infection in the host. Brucellosis is a major zoonotic disease widely distributed in both animals and humans (Delvecchio et al., 2002), especially in developing countries, where the control programs have not succeeded. The disease is a major cause of direct economic losses, so efforts have been made to prevent the disease through the use of vaccines. Similarly, control of brucellosis is dependent upon reliable methods for the identification of Brucella in livestock and humans. The genus Brucella consist of six recognized species, designated on the basis of differences in pathogenicity and host preference: $B$. melitensis (goats and sheep), B. abortus (cattle and bison), B. Sui (swine), B. ovis (sheep), B. canis (dogs) and B. neotomae (wood rats) (Corbel, 1985). The discovery of Brucella in a wide variety of marine mammals has led to the proposal of new species: $B$. Ceti and B. pinnipedialis (Foster et al., 2007). Some of species include several biovar, which are currently distinguished from each other by an analysis of approximately 25 phenotypic characteristics, including requirement for $\mathrm{CO}_{2}, \mathrm{H}_{2} \mathrm{~S}$ production, sensitivity to dyes and phages, and other metabolic properties (Alton et al., 1988). However, all these tests are timeconsuming, require skillful technicians and some of the essential reagents are not commercially available. In addition, handling of this microorganism represents a high risk for laboratory personnel, since most Brucella strain are highly pathogenic for humans. Accurate diagnostic and typing procedures are critical for the success of the eradication and control of the disease, and therefore the identification of the different species is of great epidemiological importance. The serological procedures being used in the diagnosis of animal brucellosis are mainly based on the detection of antibodies directed against the lipopolysaccharide (LPS) portion of the cell membrane. Therefore, it is difficult to differentiate between vaccinated and infected animals. In addition, tests based on anti-LPS antibodies give false positives because of crossreactivity with other Gram-negative bacteria like Yersinia O: 9, Salmonella species, Escherichia coli (Corbel, 1985; KittelBerger et al., 1995 and Weynants et al., 1996). To overcome most of these difficulties, this study was designed for using a multiplex PCR assay for molecular typing of Brucella species. However, one of the challenges of using DNA -based

\footnotetext{
* Corresponding author Dr. Rania Abo-Sakaya. Department of Animal Medicine, Faculty of Veterinary Medicine, Benha University
} 
techniques for differentiating the various Brucella species and strains is their high degree of genetic homology (OIE. 2008), this article describes the evaluation of a multiplex PCR.

\section{MATERIAL AND METHODS}

\section{Bacterial strains:}

Three lyophilized vaccinal strains [B. abortus biovar 1 (S19 and RB51) and B. melitensis biovar 1 (Rev-1)] and one reference strain $[B$. melitensis biovar 1 (16M) were supplied by CITA Institute, Zaragoza, Spain, a field isolate $B$. melitensis biovar 3 that has been isolated from an infected ewe and Yersinia enterocolitica O: 9 was kindly provided by the Brucella Department, Animal Health Research institute, Dokki, Giza. Typical $Y$. enterocolitica colonies have a" bull's eye" were chosen (UK Standard for Microbiology Investigation, 2015). The lyophilized vaccines were reconstituted in $4 \mathrm{ml}$ vaccine diluent were forwarded to genomic DNA extraction, while reference strain and local field isolate were grown separately on trypticase soya agar enriched with $0.1 \%$ yeast extract at $37{ }^{\circ} \mathrm{C}$ for 48 hours in $5 \% \mathrm{CO}_{2}$ atmosphere and $Y$. enterocolitica $\mathrm{O}: 9$ was grown on Cefsulodin, Irgasan, Novobiocin (CIN) agar at $30{ }^{\circ} \mathrm{C}$ for 24-48 hrs. A pure culture of each strain was harvested in normal saline and pelleted by centrifugation $(1700 \times \mathrm{g})$, the pellet of each strain was washed twice with $0.85 \%$ normal saline to ready for DNA extraction. The abovementioned strains were identified morphologically, biochemically and serologically. Moreover, they have been grown on media containing different stains and antibiotics (Alton et al., 1988) to identify vaccinal strains from other Brucella reference strain and field isolate and the results were compared with those obtained by multiplex PCR method.

Extraction of genomic DNA from Bacterial strains: Genomic DNA extraction was performed using Wizard Genomic DNA purification kit (Promega, USA).

\section{Multiplex PCR method:}

In this study, a multiplex PCR assay was performed according to (Dubray et al., 1985). Five primer pairs (Bioneer, Germany) (Table 1), designed on the strain specific genetic differences, were used in multiplex for molecular typing of different Brucella species and it was used to differentiate between the Brucella strains and Yersinia enterocolitica $\mathrm{O}$ : 9. In this study six multiplex PCR reaction mixtures each of $25 \mu$ volume containing $1 \mu \mathrm{l}$ of template DNA, $200 \mu \mathrm{M}$ of each deoxynucleoside triphosphate (Fermentas), 2.5 units of Dream Taq Green DNA polymerase (Fermentas), $5 \mu 1$ of its amplification buffer, and 20 pmole of each primer, were added. The PCR amplification was carried out using Gene Amp. PCR system 9700 thermal cycler (Applied Bio systems, USA). The cycling condition were 7 minutes at $95{ }^{\circ} \mathrm{C}$ for initial denaturation, 25 cycles each of 30 seconds at $94{ }^{\circ} \mathrm{C}$ for denaturation, 30 seconds at $64{ }^{\circ} \mathrm{C}$ for primer annealing, 1 minute and 40 seconds at $72{ }^{\circ} \mathrm{C}$ for extension of the amplicons, and one cycle at $72{ }^{\circ} \mathrm{C}$ for 7 minutes for final extension. The PCR amplicons were analyzed by running $10 \mu \mathrm{l}$ of the PCR products in $1 \%$ agarose gel stained with ethidium bromide $(0.5 \mu \mathrm{g} / \mathrm{ml})$.
Amplification pattern of each Brucella species was determined according to molecular size of the amplified products (Figure 1). Whole genome sequences of B. melitensis (Corbel, 1988) and B. abortus (Garcia-Yoldi, 2006) were used.

\section{RESULTS}

In the present study, five Brucella strains (one local isolate, three vaccinal strains and one reference virulent strain) have been identified using traditional and recent methods. The local field isolate was recovered from ewe clinically diagnosed as brucellosis. The vaccinal strains were Brucella abortus S19, RB51 and Brucella melitensis Rev-1 which represent live attenuated vaccines against brucellosis. The one reference virulent strain was $B$. melitensis $16 \mathrm{M}$ biovar1. The five strains were traditionally identified using the most common methods, whereas the eultivation cultural characters were consistent with the typical characters of Brucella species. All strains grew within 3 days as raised, convex, circular colonies with smooth surface. The vaccinal strain RB51 showed rough colonies which take red stain when stained with crystal violet and can resist and grow in media containing rifampicin (250 $\mu \mathrm{g} / \mathrm{ml}$ media).

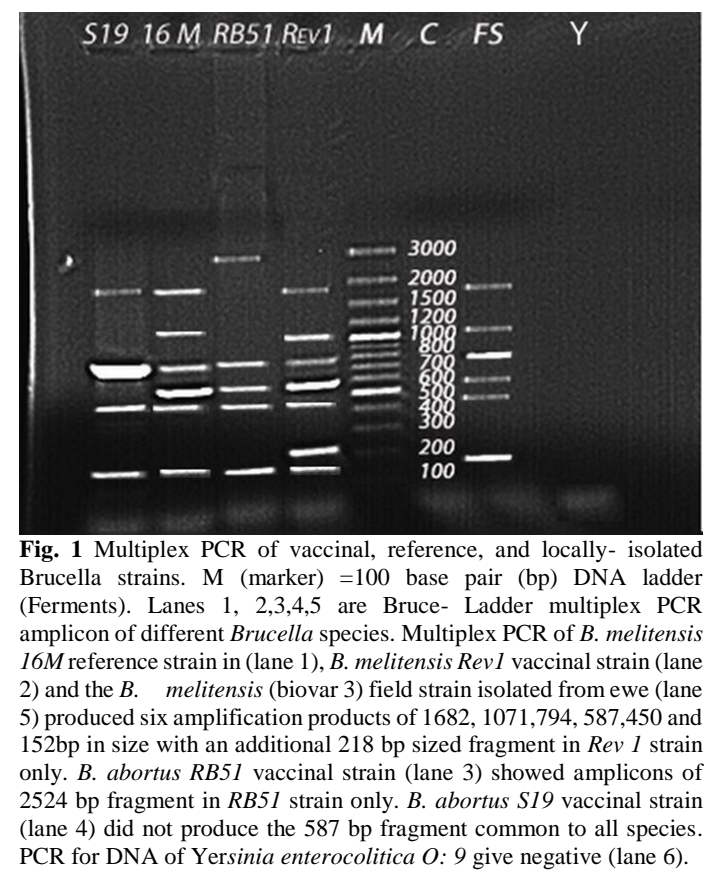

The vaccinal strain S19 revealed smooth colonies which have not been stained with crystal violet and could not grow on media containing thionin blue (20 $\mu \mathrm{g} / \mathrm{ml})$, erythritol $(1 \mathrm{mg} / \mathrm{ml})$ and penicillin $(5 \mathrm{IU} / \mathrm{ml})$ in contrast to other strains. On the other hand, the vaccinal strain Rev-1 produced smooth colonies which have not been stained with crystal violet and could not grow on media containing thionin $(20 \mu \mathrm{g} / \mathrm{ml})$, basic fuchsine $(20 \mu \mathrm{g} / \mathrm{ml}$ and penicillin $(5 \mathrm{IU} / \mathrm{ml})$ but grew on media containing streptomycin $(2.5 \mu \mathrm{g} / \mathrm{ml})$, in contrast to other strains. The biochemical method confirmed that S19 and RB51, each behaved as B. abortus while Rev1, 16M strains were B. melitensis-like in their biochemical tests. 
Table 1 Primer sets for multiplex PCR.

\begin{tabular}{|c|c|c|c|c|}
\hline Primer & Sequence $(5, \ldots 3)$ & & $\begin{array}{l}\text { DNA } \\
\text { targets }\end{array}$ & $\begin{array}{l}\text { Source of genetic } \\
\text { difference }\end{array}$ \\
\hline BME10998F & ATC-CTA-TTG-CCC-CGA-TAA-GG & 1682 & $\begin{array}{l}\text { Glycosyl transferase, } \\
\text { gene wboA }\end{array}$ & $\begin{array}{l}\text { S711 insertion in } \\
\text { B. abortus RB51. }\end{array}$ \\
\hline BME10997R & GCT-TCG-CAT-TTT-CAC-TGT-AGC & & & \\
\hline $\begin{array}{l}\text { BMEII0843F } \\
\text { bp in } \\
\text { BMEII0850 } \\
\text { BMEII0844R }\end{array}$ & TTT-ACA-CAG-GCA-ATC-CAG-CA & 1071 & $\begin{array}{l}\text { Outer membrane } \\
\text { Protein, gene omp } 31\end{array}$ & $\begin{array}{l}\text { deletion of } 25,061 \\
\text { BMEII826- } \\
\text { in B. abortus }\end{array}$ \\
\hline $\begin{array}{l}\text { BMEII0428F } \\
\text { BMEII0428 } \\
\text { BMEII0428R }\end{array}$ & GCC-GCT-ATT-ATG-TGG-ACT-GG & 587 & $\begin{array}{l}\text { Erythritol catabolism, } \\
\text { gene ery C (D-erythrulose } \\
\text {-1-phosphate dehydrogenase) }\end{array}$ & $\begin{array}{l}\text { deletion of } 702 \text { bp in } \\
\text { BMEII0427 - } \\
\text { in B.abortus } S 19\end{array}$ \\
\hline $\begin{array}{l}\text { BR0953F } \\
\text { in } \\
\text { abortus } \\
\text { BR0953R }\end{array}$ & GGA-ACA-CTA-CGC-CAC-CTT-GT & 272 & $\begin{array}{l}\mathrm{ABC} \text { transporter binding } \\
\text { Protein }\end{array}$ & $\begin{array}{l}\text { deletion of } 2653 \mathrm{bp} \\
\text { BR0 } 951 \mathrm{BR} 0955 \text { in } B . \\
\text { and B. melitensis }\end{array}$ \\
\hline $\begin{array}{l}\text { BMEI0752F } \\
\text { BMEI0752R }\end{array}$ & $\begin{array}{l}\text { CAG-GCA-AAC-CCT-CAG-AAG-C } \\
\text { GAT-GTG-GTA-AGG-CAC-ACC-AA }\end{array}$ & 218 & $\begin{array}{l}\text { Ribosomal protein S12, } \\
\text { gene rpsL }\end{array}$ & $\begin{array}{c}\text { point mutation in } \\
\text { B.melitensis Rev.1 }\end{array}$ \\
\hline
\end{tabular}

Table 2 Species and biovar biochemical and morphological differentiation of the Brucella strains.

\begin{tabular}{|c|c|c|c|c|c|}
\hline & \multicolumn{5}{|c|}{ Brucella Spp. } \\
\hline & \multicolumn{2}{|c|}{ Brucella abortus } & \multicolumn{3}{|c|}{ Brucella melitensis } \\
\hline & $\mathrm{S} 19$ & RB51 & Rev 1 & $16 \mathrm{M}$ & Field isolate \\
\hline Morphology & Gram & negative & Small & Coccobacilli & \\
\hline Lactose fermentation on MacConkey agar & - & - & - & - & - \\
\hline Hemolysis on blood agar & - & - & - & - & - \\
\hline Catalase test & + & + & + & + & + \\
\hline Nitrate reduction test & + & + & + & + & + \\
\hline Urease test & + & + & + & + & + \\
\hline Oxidase test & + & + & + & + & + \\
\hline Colonial morphology & Smooth & Rough & Smooth & Smooth & Smooth \\
\hline $\mathrm{CO}_{2}$ requirement & - & + & - & - & - \\
\hline $\mathrm{H} 2 \mathrm{~S}$ production & + & + & - & - & - \\
\hline \multicolumn{6}{|l|}{ Growth on dyes } \\
\hline 1-Thionin $1: 50,000 \quad(20 \mu \mathrm{g} / \mathrm{ml})$ & + & + & - & + & + \\
\hline 2-Basic fuchsine 1:50,000 $(20 \mu \mathrm{g} / \mathrm{ml})$ & + & + & - & + & + \\
\hline 3 -Thionin blue $(2 \mu \mathrm{g} / \mathrm{ml})$ & - & + & + & + & + \\
\hline Growth in the presence of erythritol $(1 \mathrm{mg} / \mathrm{ml})$ & - & + & + & + & + \\
\hline \multicolumn{6}{|l|}{ Growth in the presence of antibiotic } \\
\hline 1- Streptomycin $(2.5 \mu \mathrm{g} / \mathrm{ml})$ & - & - & + & - & - \\
\hline 2- Penicillin (5 IU/ml) & - & + & + & + & + \\
\hline 3- Rifampicin $(250 \mu \mathrm{g} / \mathrm{ml})$ & - & + & - & - & - \\
\hline
\end{tabular}

Table 3 Species and biovar serological differentiation of the collected Brucella strains.

\begin{tabular}{|c|c|c|c|}
\hline \multirow{2}{*}{ Brucella species } & \multicolumn{3}{|c|}{ Monospecific antisera } \\
\hline & A & M & $\mathrm{R}$ \\
\hline B. abortus S-19 ( biotype 1) & + & - & - \\
\hline B. abortus S-RB51( biotype 1) & + & - & + \\
\hline B. melitensis Rev-1(biotype 1) & & + & - \\
\hline B. melitensis $16 \mathrm{M}$ (biotype 1) & - & + & - \\
\hline B. melitensis local field isolate (biotype 3 ) & + & + & - \\
\hline
\end{tabular}


However, Egyptian field isolate was identified as $B$. melitensis according to biochemical identification (Table 2 and 3). Three monospecific antisera (A, M and $\mathrm{R})$ were used in identification. Where strain 19 crossreacted with the strain RB51 monospecific antiserum A as it is B. abortus, the vaccinal strain RB51 reacted with the monospecific antiserum R. The Rev-1 and $16 \mathrm{M}$ strains agglutinated with the monospecific antiserum $\mathrm{M}$ as they are $B$. melitensis biovar1. The field isolate agglutinated with both $\mathrm{M}$ and $\mathrm{R}$ monospecific antisera which indicated that this strain is $B$. melitensis biovar3. Molecular characterization trials have been carried out to differentiate the different Brucella species and biovar. DNA dependent methods have been recently nominated as tools for identification and differentiation of Brucella isolates. While lots of methods were used for genomic characterization of Brucella, the restriction fragment length polymorphism (RFLP) and PCR were the most commons. Yersinia enterocolitica O: 9 was cultured on Cefsulodin, Irgasan, and Novobiocin (CIN) agar at $30^{\circ} \mathrm{C}$ for $24-48$ hrs prior to DNA extraction. Typical $Y$. enterocolitica colonies having a "bull's eye" were chosen. Detection of the unique genomic differences of Brucella species were based on published whole genome sequences of B. melitensis and B. abortus used in this study (Table 1). Brucella species were differentiated based on the size of the produced amplicons. In Multiplex PCR assay using DNA from B. melitensis strains, six fragments were amplified: of 1,682, 1,071,794,587,450 and 152 bp in size with an additional 218 bp sized fragment in Rev-1 strain only produced by the BMEI0752 primer pair (Table 1). PCR using DNA from $B$. abortus strains amplified five fragments, of $1,682,794,587,450$ and $152 \mathrm{bp}$ in size. On the other hand, $B$. abortus RB51 vaccinal strain did not produce the $1682 \mathrm{bp}$ fragment due to disruption of the wboA gene by an IS711 element in B. abortus RB51. In addition the aforementioned results led to the conclusion that the multiplex PCR has successfully identified as well as differentiated each of the tested Brucella species and the vaccine strains in the same test and also to differentiate between Brucella strains and $Y$. enterocolitica $\mathrm{O}: 9$ which give negative. In addition, a multiplex PCR assay confers several advantages over the current identification methods the major advantage is the speed with which the assay can be performed together with minimal sample preparation, whereas only 104 bacteria can be added directly to the reaction mixture.

\section{DISCUSSION}

Identification of different members of Brucella has been done with the traditional methods such as cultural, biochemical characterization and serological identification (Alton et al., 1988). Recent methods were also introduced to the field of laboratory identification of Brucella (Godfroid et al., 2002). In the present study, five Brucella strains (one local isolate, three vaccinal strains and one reference virulent strain) have been identified using traditional and recent methods; the local field isolate was recovered from ewe clinically diagnosed as brucellosis. All strains grow within 3 days as raised, convex, circular colonies with smooth surface. Gram and Modified Ziehl-Neelsen stained films showed Gram-negative or pink, weak acid fast short rods with round ends and slightly convex sides (Jensen et al., 1995). The vaccinal strain RB51 showed rough colonies which take red stain when stained with crystal violet and can resist and grow in media containing rifampicin $(250 \mu \mathrm{g} / \mathrm{ml}$ media). These results were consistent with that recorded by Alton et al. (1988) and Jensen et al. (1995).

In the present study, genomic DNA was extracted and a multiplex PCR assay was used to identify as well as to differentiate Brucella vaccinal strains from other Brucella species and biovar, besides a field isolate and to differentiate between Brucella strains and Enterocolitica O: 9. Previously designed five multiplex primer sets (Dubray, 1985). Typical Y. enterocolitica colonies having a" bull's eye" were chosen. Detection of the unique genomic differences of Brucella species was based on published whole genome sequences of B. melitensis (Corbel, 1988) and B. abortus (GarciaYoldi, 2006) were used in this study. PCR of RB51 was characterized by a specific additional band of $2524 \mathrm{bp}$ size, a similar result was reported by KittelBerger et al. (1995) and Halling et al. (2005). The BMEI0752 primer pair detected a unique point mutation in the rpsL gene, coding for the Ribosomal protein $\mathrm{S} 12$, of the vaccinal strain B. melitensis Rev-1 and responsible for Streptomycin resistance of Rev-1 (Cloeckaret et al., 2002). PCR with B. abortus S19 did not produce the 587 bp fragment, common to all Brucella species due to deletion of 702 bp in the Erythroid catabolism gene eryC (Lopez-Goni et al., 2008) leading to miss priming of the BMEI0428 primers pair. On the other hand, B. abortus RB51 vaccinal strain did not produce the 1682 bp fragment due to disruption of the wboA gene by an IS711 element in B. abortus RB51.

\section{CONCLUSION}

Multiplex PCR assay is recommended for testing the seed cultures commonly used in the production of live Brucella vaccines (Rev-1, S19 and RB51 vaccines) and in evaluating them in quality control laboratories.

\section{REFERENCES}

1. Alton, G.G, Jones, L.M, Angus, R.D. and Verger, J.M. 1988. Techniques for the brucellosis laboratory. (Institute National de la Recherché Agronomies') INRA. Paris

2. Cloeckaret, A., Grayon, M., and Grepinet, O. 2002. Identification of Brucella melitensis vaccine strain Rev. 1 by PCR-RFLP based on a mutation in the rpsL gene. Vaccine 20: 2546 - 2250.

3. Corbel, M.J. 1985. Recent advances in the study of Brucella antigens and their serological cross reactivity. Vet. Bull. (55): 927-42.

4. Corbel, M.J. 1988. International committee on the systematic bacteriology subcommittee on the taxonomy of Brucella. Int. J. Syst. Evol. Microbiol. 57: 2688 2693.

5. Delvecchio, V.G, Kapatral, V., Redka, R.J., Patra, G., Mujer, C. and Los, T. 2002. The Genome sequence of the facultative intracellular pathogen Brucella melitensis. Proc. Natl. Acad. Sci. USA. 99: 443-448.

6. Dubray, G. 1985. Antigens of diagnostic significance in Brucella. In: Verger JM, Plommet M, editors. Brucella melitensis, a CEE seminar. The Hague, the Netherlands: Martinus Nijhof Publishing: 123-138. 
7. Foster, G., B.S. Osterman, J. Godfroid, I. Jacques, and A. Cloeckaret. 2007. Brucella Ceti sp. Nov. and Brucella pinnipedialis sp.Nov. For Brucella strains with cetaceans and seals as their preferred hosts. Int. J. Syst. Evol. Microbiol. 57: 2688 - 2693.

8. Garcia-Yoldi D., Marin, C.M., De Miguel, M.J., Munoz, P.M., Vizcaino's J. L. and Lopez-Goni, I. 2006. Multiplex PCR assay for the identification and differentiation of all Brucella species and the vaccine strains Brucella abortus S19 and RB51 and Brucella melitensis Rev1. Clin. Chem. 52: 779 - 781.

9. Godfroid, J., Bosman PP and Bishop, G.C. 2002. Bovine brucellosis. In: Infectious Diseases of Livestock, $2^{\text {nd }} \mathrm{Ed}$ : J.A.W. Coetzer and R.C. Tustin, Oxford University Press, Cape Town. pp 15101-1527.

10. Halling, S.M., Peterson-Burch, B.D., Bricker, B.J., Zuerner, R.L., Qing, Z., Li LL, Kapur, V., Alt, D.P. and Olsen, S.S. 2005. Completion of the genome sequence of Brucella abortus and comparison to the highly similar genomes of Brucella melitensis and Brucella suis. J. Bacterial. 187: 2715-2726.

11. Jensen, A.E., Chenille, N.F., Ewalt, D.R., Payeur, J.B. and Thoen, C.O. 1995. Application of pulsed-field gel electrophoresis for differentiation of vaccine strain RB51 from field isolates of Brucella abortus from cattle, bison, and elk.Am.J.Vet.Res.56: 308-312.

12. KittelBerger, R., Hilbink, F., Hansen, M.F., Penrose, M., De lisle, G.W., Letesson, J.J., Garin-Bastuji, B., Searson, J., Fossati, C.A., Cloeckaert, A. and Schurig, G. 1995. Serological cross reactivity between Brucella abortus gene and serological evaluation of the 17-kilo Dalton antigen that it encodes. Clin. Diagn. Lab. Immunology. (2):263-267.

13. Lopez-Goni, I., Garcia Yoldi, D., Marin, C.M., de Miguel, M.J., Munoz, P.M, Blasco, J.M., Jacques, I.,
Grayon, M., Cloeckaret, A., Ferreira, A.C., Cardoso, R., Correa de Sa, M. I., Walgreens, K., Albert, D. and Garin Bastuji, B. 2008. Evaluation of a Multiplex PCR Assay (Bruce-ladder) for Molecular Typing of all Brucella species, including the vaccine strains. J. Clin. Microbiol. 46: 3484 - 3487.

14. OIE. 2008. Manual of Diagnostic Tests and vaccines for Terrestrial Animals (mammals, birds and bees) $6^{\text {th }}$ Edition, 2008.

15. Rajashekara, G., Glasner, J.D., Glover, D.A. and Splitter, G.A. 2002. Comparative whole-genome hybridization reveals genomic islands in Brucella species. J. Bacterial. 186:5040-5051.

16. Sangari, F.J., Garcia-lobo, J.M. and Aguero, J. 1994.The Brucella abortus vaccine strain B19 carries a deletion in the erythritol catabolic genes. FEMS Microbiol let. 121: 337-342.

17. Verger, J.M., Grimond, F., Grimond, P. A. D. and Grayon, M. 1985. Brucella, a monospecific genus as shown by deoxyribonucleic acid hybridization. Int. J. Syst. Bacterial. 35: 292 - 295.

18. Weynants, V., Tibor, A., Denoel, P., Saegerman, C., Godfroid Letesson, J.J. 1996. Evaluation of an ELISA using Yersinia outer membrane proteins of the involvement of Yersinia enterocolitica O: 9 in the false positive serological responses observed in bovine brucellosis diagnostic tests. Vet. Microbiology. (48): 101-112.

19. Wright, P.F. and Nielsen, K.H. 1990. Current and future serological methods. In: Adams LG, editor. Advances in brucellosis research. College Station, Texas: Texas A\&M University Press: 305-320.

20. UK Standard for Microbiology Investigation, Public Health England 2015. Identification of Yersinia species. ID 21 No. (3): 1-22. 